\title{
Dukungan Sosial Keluarga dengan Minat Berwirausaha Siswa Sekolah Menengah Kejuruan (SMK)
}

\author{
Yosy Wijaya ${ }^{1}$ \\ Fakultas Psikologi, Program Studi Psikologi, Universitas Setia Budi Surakarta \\ yosywijaya123@gmail.com \\ Aditya Nanda Priyatama ${ }^{2}$ \\ Fakultas Kedokteran, Program Studi Psikologi, Universitas Sebelas Maret \\ aditya_npriyatama@staff.uns.ac.id \\ Mohammad Khasan ${ }^{3}$ \\ Fakultas Psikologi, Program Studi Psikologi, Universitas Muria Kudus \\ mohammad.khasan@umk.ac.id
}

\begin{abstract}
Unemployment and poverty have become major problems in Indonesia, based on data from the Indonesian Central Statistics Agency (BPS), it is said that the unemployment rate in Indonesia in February 2017 the lowest open unemployment was at the elementary school level (SD) and below, namely 3.54\%, the open unemployment rate in the education sector from the junior high school level (SMP) 5.36\%, Senior High School (SMA) 7.03\%. Vocational High School (SMK) 9.27\%. Diploma III (D3) of $6.35 \%$. The objective of this quantitative research was to identify the correlation between family social support and entrepreneurship interest on students of SMK Negeri 4 Surakarta. A group of students of SMK Negeri 4 Surakarta was taken as research subject which involved 117 students as research sample from the total population of 468 students in this school. The sample was taken using cluster random sampling technique. Likert scales for family social support and entrepreneurship interest were employed as measurement tools in collecting data. The data were analyzed using Karl Pearson's Product-Moment Correlation supported. This research proposed a hypothesis that there is a positive correlation between family social support and entrepreneurship interest on students. The analysis result shows that correlation coefficient is rxy $=0.477$ with $p=0.000(p<0.01)$. This proves that there is a significant positive correlation between family social support and entrepreneurship interest. Therefore the hypothesis proposed in this research is accepted. This means that there is a relationship between family social support and interest in entrepreneurship in students of SMK Negeri 4 Surakarta
\end{abstract}

Keywords: Entrepreneurship Interest, Family Social Support, Vocational high school students.

\begin{abstract}
Abstrak
Pengangguran dan kemiskinan masih menjadi permasalahan utama di negara Indonesia, berdasarkan data Badan Pusat Statistik (BPS) Indonesia, mengatakan bahwa tingkat pengangguran di Indonesia pada bulan Februari 2017 pengangguran terbuka terendah berada di jenjang pendidikan Sekolah Dasar (SD) ke bawah yakni 3,54\%, Tingkat pengangguran terbuka sektor pendidikan dari jenjang Sekolah Menengah Pertama (SMP) sebesar 5,36\%, Sekolah Menengah Atas (SMA) sebesar 7,03\%. Sekolah Menengah Kejuruan (SMK) 9,27\%. Diploma III (D3) sebesar 6,35\%. Penelitian ini bertujuan untuk mengetahui hubungan antara dukungan sosial keluarga dengan minat berwirausaha pada siswa SMK negeri 4 Surakata. Hipotesis yang diajukan yaitu terdapat hubungan yang positif antara dukungan sosial keluarga dengan minat berwirausaha pada siswa. Metode dalam penelitian ini menggunakan metode kuantitatif dan teknik pengambilan sampelnya dilakukan dengan menggunakan teknik cluster random sampling. Subjek dalam penelitian ini adalah siswa SMK negeri 4 Surakarta yang berjumlah 117 siswa. Alat ukur yang digunakan dalam penelitian ini adalah skala dukungan sosial keluarga dan minat berwirausaha. Metode analisis data yang digunakan adalah korelasi Product Moment dari Karl Pearson. Hasil analisis menunjukan koefisien
\end{abstract}


korelasi sebesar rxy $=0,477$ dengan $p=0,000(p<0.01)$. Hal tersebut membuktikan terdapat hubungan positif yang sangat signifikan antara dukungan sosial keluarga dengan minat berwirausaha, sehingga hipotesis yang diajukan dalam penelitian ini diterima. Ini berarti terdapat hubungan antara dukungan sosial keluarga dengan minat berwirausaha pada siswa SMK negeri 4 Surakarta

Kata kunci: Dukungan Sosial Keluarga, Minat Berwirausaha, Siswa SMK.

\section{PENDAHULUAN}

Pengangguran dan kemiskinan masih menjadi permasalahan utama di negara Indonesia, jumlah penawaran kerja tidak sebanding antara jumlah lulusan dengan penawaran lowongan kerja di segala tingkat pendidikan sehingga mengakibatkan banyaknya pengangguran dan kemiskinan saat ini (Saiman, 2009). Sebenarnya Indonesia sudah dihadapkan pada maraknya pengangguran terdidik yang semakin tahun semakin tinggi, banyaknya pengangguran saat ini semakin terlihat dengan ditunjukan adanya krisis global (Hendro, 2011). Hal ini didukung oleh penemuan hasil dari data Badan Pusat Statistik (BPS) Indonesia, mengatakan bahwa tingkat pengangguran di Indonesia pada bulan Februari 2017 pengangguran terbuka terendah berada di jenjang pendidikan Sekolah Dasar (SD) ke bawah yakni 3,54\%, tingkat pengangguran terbuka sektor pendidikan dari jenjang Sekolah Menengah Pertama (SMP) sebesar 5,36\%, Sekolah Menengah Atas (SMA) sebesar 7,03\%. Sekolah Menengah Kejuruan (SMK) 9,27\%. Diploma III (D3) sebesar 6,35\%. (hhtp//www.bps.go.id).

Penyebab banyaknya pengangguran di Indonesia karena sebagian besar orang belum memiliki jiwa wirausahawan, banyak faktor penyebabnya diantaranya disebabkan lingkungan keluarga, kebiasaan kerja, tidak memiliki pengalaman, tidak mempunyai modal, tidak memiliki keberanian untuk keluar dari "zona nyaman" yang takut akan kegagalan dan kerugian dan tidak memiliki keberanian untuk memutuskan menjadi wirausahawan (Hendro, 2011). Masyarakat di Indonesia belum banyak yang berkeinginan untuk menjadi wirausahawan, hal ini disebabkan karena adanya faktor yang membentuk sikap negatif terhadap profesi wirausahawan diantaranya sifat agresif, bersaing, tidak jujur, ekspansif, egois, kikir dan sumber dalam penghasilannya tidak dapat stabil. Mindset itu diyakini oleh sebagian besar masyarakat negara Indonesia, sehingga banyak yang tidak berkeinginan untuk terjun ke dunia wirausaha (Alma, 2016).

Upaya yang dapat dilakukan dalam mengurangi tingkat pengangguran ialah dengan cara mengubah pola pikir masyarakat yang berkeinginan untuk mencari kerja berubah menjadi membuka atau menciptakan lapangan pekerjaan sendiri dengan memulai usaha kecil-kecilan 
sendiri, dengan begitu dapat membantu mengurangi pengangguran di Indonesia. Cara yang dapat dilakukan dengan berwirausaha (Hendro, 2011).

Berwirausaha sangatlah penting bagi masyarakat, karena dengan berwirausaha masyarakat tidak lagi bergantung dengan lapangan pekerjaan, dan menciptakan peluang kerja bagi orang lain. Dimana lapangan pekerjaan yang tersedia saat ini semakin lama semakin sempit karena banyaknya persaingan yang terjadi antara pencari kerja. Kegiatan berwirausaha dalam masyarakat memiliki peranan yang sangat penting untuk membantu mengatasi masalah pengangguran di Indonesia, melancarkan proses produksi, distribusi, dan konsumsi bagi negara dan meningkatkan pendapatan masyarakat, sehingga dibutuhkan kemampuan berwirausaha (Alma, 2016)

Berdasarkan hasil wawancara dengan salah satu siswa SMK Negeri 4 Surakarta berinisial E pada tanggal 15 Desember 2017, menyatakan bahwa: "saya tertarik berwirausaha setelah lulus, tapi saya masih ragu dengan keinginan saya untuk berwirausaha, karena saya belum memiliki kepercayaan diri serta saya tidak memiliki modal dan pengalaman untuk membuka usaha sendiri, saya belum yakin untuk membuka usaha karena takut gagal dan tidak berani mengambil resiko. Orang tua saya lebih menginginkan saya kuliah supaya saya dapat menjadi PNS". Berdasarkan pernyatan siswa E diatas dapat disimpulkan bahwa siswa cenderung berkeinginan untuk membuka wirausaha setelah lulus namun belum memiliki keyakinan yang pasti. Alasan yang dikemukakan siswa tersebut karena kurangnya kepercayaan diri atas kemampuan yang dimilikinya, tidak memiliki pengalaman dan modal untuk membuka usaha, membuat siswa tidak yakin untuk membuka usahanya karena takut gagal dan tidak berani mengambil resiko. Selain itu dari pihak keluarga terutama orang tua berkeinginan anaknya untuk melanjutkan ke perguruan tinggi, yang harapannya nanti setelah sarjana bisa menjadi Pegawai Negeri Sipil (PNS).

Berdasarkan hasil wawancara diatas menunjukkan bahwa siswa cenderung berkeinginan untuk membuka wirausaha setelah lulus namun belum memiliki keyakinan yang pasti. Alasan yang dikemukakan siswa tersebut karena kurangnya tekad dan kepercayaan diri terhadap kemampuan yang sudah dimilikinya, tidak memiliki pengalaman dan modal untuk membuka usaha, menjadikan pola pikir siswa cenderung negatif terhadap dunia wirausaha karena takut gagal dengan risiko yang harus ditanggung nantinya, selain itu dari orang tua mengharapkan anaknya untuk menjadi pegawai negeri sipil (PNS) dengan upaya melanjutkan ke perguruan tinggi. 
Dalam hal ini pemikiran keluarga terutama orang tua masih mengarahkan anak-anaknya agar menjadi PNS karena orang tua berpikir PNS merupakan pekerjaan yang menjanjikan sedangkan berwirausaha merupakan pekerjaan yang belum tentu menjanjikan untuk masa depan anak. Sehingga pemikiran yang seperti itu mempengaruhi perilaku dan pola pikir anak nantinya. Hal ini selaras dengan pendapat Aprilianty (2012), bahwa pembentukan minat berwirausaha disebabkan oleh banyak faktor diantaranya pola pikir dalam keluarga yang menuntut utuk menjadi PNS, keterbatasan pengetahuan orang tua, tidak memiliki model wirausahawan dalam keluarga, karyawan lebih aman daripada menjadi wirausahawan.

Menurut Wibowo (2011), faktor timbulnya minat berwirausaha adalah lingkungan keluarga terutama orang tua, lingkungan keluarga merupakan sekumpulan seseorang yang terdiri dari ayah, ibu, anak dan anggota lainnya dalam keluarga. Di lingkungan ini merupakan dasar bagi perkembangan dan pertumbuhan anak yang memberikan pengaruh pertama terhadap terbentuknya kepribadian, kreatifitas dan rasa tanggung jawab dapat diajarkan sedini mungkin saat anak mulai berinteraksi dengan orang dewasa.

Lingkungan keluarga merupakan lingkungan pertama bagi individu, dimana individu banyak menghabiskan sebagian waktunya di rumah. Hal ini sesuai yang dikemukakan Ihsan (2011) bahwa Keluarga adalah lembaga pendidikan yang utama dalam masyarakat, dalam keluargalah kepribadian manusia itu dibentuk dan tumbuh menjadi individu dewasa. Sehingga perkembangan dan pola pikir anak dipengaruhi oleh kebiasaan dan didikan orang tua.

Individu memerlukan dukungan sosial keluarga berupa informasi dan nasehat dari orang tua, karena lingkungan keluarga khususnya orang tua memiliki peran penting dalam memotivasi anak agar terlibat dalam wirausaha meskipun orang tua seorang pengusaha maupun tidak (Apriliyanti, 2012). Menurut Alma (2016) Dukungan sosial keluarga dapat dilihat dari seberapa jauh orang tua berperan dalam kehidupan anaknya. Dorongan orang tua, saudara cukup berpengaruh terhadap semangat berwirausaha, karena dapat berdiskusi dengan bebas, dibandingkan dengan orang lain. Keluarga biasa memberikan dorongan, pengertian, motivasi, bahkan bantuan, sehingga dukungan keluarga menunjukan bahwa lingkungan keluarga sangat berpengaruh dalam menumbuhkan minat berwirausaha. Hal ini sesuai dengan teori Darpujiyanto (2010) yaitu minat berwirausaha akan terbentuk dalam diri individu apabila orang tua memberikan dukungan positif terhadap minat tersebut, karena aktifitas sesama anggota keluarga akan mempengaruhi baik secara langsung maupun tidak langsung. 
Rumusan Masalah, berdasarkan uraian latar belakang di atas maka rumusan masalah dari penelitian yaitu apakah terdapat hubungan antara dukungan sosial keluarga dengan minat berwirausaha pada siswa SMK Negeri 4 Surakarta.

Penelitian ini bertujuan untuk mengetahui Hubungan antara Dukungan Sosial Keluarga dengan Minat Berwirausaha pada siswa SMK Negeri 4 Surakarta.

\section{METODE}

Penelitian ini menggunakan pendekatan kuantitatif. Minat berwirausaha merupakan variabel tergantung, sedangkan dukungan sosial keluarga merupakan variabel bebas.

Sampel, metode yang digunakan untuk pengambilan sampel adalah teknik Cluster Random Sampling. Subjek dalam penelitian ini adalah siswa/siswi SMK Negeri 4 Surakarta yang berjumlah 117 orang dengan karakteristik populasi yaitu siswa/siswi kelas XI jurusan tata boga.

Pengumpulan dan analisis data, metode pengumpulan data dalam penelitian ini menggunakan metode skala. Terdapat dua macam skala yang digunakan, skala minat berwirausaha yang disusun berdasarkan karakteristik dari Marbun (dalam Alma, 2016) yaitu percaya diri, pengambilan resiko, berorientasi tugas dan hasil, keorisinilan, kepemimpinan, dan berorientasi ke masa depan. Skala dari minat berwirausaha terdiri dari 42 aitem dan skala dukungan sosial keluarga disusun berdasarkan aspek House (1987) yaitu aspek dukungan emosional, dukungan penghargaan, dukungan instrumental, dukungan informatif. Skala dari dukungan sosial keluarga terdiri dari 38 aitem. Teknik analis data yang digunakan dalam penelitian ini adalah korelasi product moment dari karl pearson dengan bantuan SPSS 21.0.

\section{HASIL DAN PEMBAHASAN}

Uji coba alat ukur dalam penelitian ini dilakukan pada tanggal 25 Mei 2018-27 Mei 2018. Peneliti memberikan skala minat berwirausaha dan skala dukungan sosial keluarga langsung kepada responden. Pembagian skala dilakukan di kelas masing-masing. Skala minat berwirausaha terdiri atas 42 aitem yang terbagi menjadi pernyataan Favorable sebanyak 21 aitem dan pernyataan unfavorable sebanyak 21 item. Hasil uji daya beda item skala minat berwirausaha menunjukan bahwa 42 aitem yang diuji cobakan diperoleh indeks korelasi item total $\geq 0,25$. Dengan indeks korelasi item berkisar antara 0,259 sampai dengan 0,809. Koefisien reliabilitas ditunjukan pada nilai koefisien alpha Cronbach sebesar 0,930. 
Skala dukungan sosial keluarga terdiri atas 38 aitem yang terbagi menjadi pernyataan Favorable sebanyak 19 aitem dan pernyataan unfavorable sebanyak 19 item. Hasil uji daya beda item skala minat berwirausaha menunjukan bahwa 38 aitem yang diuji cobakan diperoleh indeks korelasi item total $\geq 0,25$. Dengan indeks korelasi item berkisar antara 0,323 sampai dengan 0,841. Koefisien reliabilitas ditunjukan pada nilai koefisien alpha Cronbach sebesar 0,961. Hasil uji coba data dapat dilihat pada tabel 1 .

Tabel 1.

Hasil pelaksanaan pengambilan data

\begin{tabular}{llllll}
\hline Skala & $\begin{array}{l}\text { Jumlah } \\
\text { Aitem }\end{array}$ & $\begin{array}{l}\text { Item } \\
\text { Valid }\end{array}$ & $\begin{array}{l}\text { Item } \\
\text { Gugur }\end{array}$ & $\begin{array}{l}\text { Indeks } \\
\text { Korelasi }\end{array}$ & Alpha Cronbach \\
\hline Minat Berwirausaha & 48 & 42 & 6 & $\geq 0,25$ & 0,930 \\
$\begin{array}{l}\text { Dukungan Sosial } \\
\text { Keluarga }\end{array}$ & 40 & 38 & 2 & $\geq 0,25$ & 0,961 \\
\hline
\end{tabular}

Berdasarkan hasil analisis terhadap data penelitian, maka diperoleh deskriptif statistik data penelitian masing-masing variabel seperti yang dapat dilihat pada tabel 2 .

Tabel 2.

Deskripsi data hasil penelitian

\begin{tabular}{lllll}
\hline \multirow{2}{*}{ Statistik } & \multicolumn{2}{l}{ Minat berwirausaha } & \multicolumn{2}{l}{ Dukungan sosial keluarga } \\
\cline { 2 - 5 } & Hipotetik & Empirik & Hipotetik & Empirik \\
\hline X maximal & 168 & 165 & 152 & 150 \\
X minimal & 42 & 126 & 38 & 108 \\
Mean & 105 & 139,6 & 95 & 126,5 \\
Standar Deviasi & 21 & 8,03 & 19 & 10,88 \\
\hline
\end{tabular}

Perbandingan antara mean empirik dan mean hipotetik pada tabel 2 menjelaskan mengenai keadaan subjek penelitian pada variabel penelitian. Mean empirik variabel minat berwirausaha adalah 139,6 lebih tinggi dari pada mean hipotetiknya, yaitu 105. Artinya secara umum subjek pada penelitian ini memiliki minat berwirausaha yang tinggi. Sedangkan mean empirik variabel dukungan sosial keluarga adalah 126,5 lebih tinggi dari mean hipotetiknya, yaitu 95. Artinya subjek pada penelitian ini mempunyai dukungan sosial keluarga yang tinggi.

Berdasarkan kriteria kategori skor subjek, bahwa siswa SMK Negeri 4 Surakarta memiliki minat berwirausaha ke dalam kategori sangat tinggi dengan presentase sebanyak 
$60,7 \%$. Sedangkan untuk variabel dukungan sosial keluarga yang dimiliki siswa SMK Negeri 4 Surakarta masuk ke dalam kategori sangat tinggi 55,6\%. Dapat dilihat pada tabel 3.

Tabel 3.

Deskripsi kategorisasi tabel penelitian.

\begin{tabular}{lllll}
\hline Variabel & Kategori & Rentang Nilai & Frekuensi & $\%$ \\
\hline Minat berwirausaha & Sangat Tinggi & $136,5 \leq \mathrm{X}$ & 71 & $60,7 \%$ \\
\cline { 2 - 5 } & Tinggi & $115,5<\mathrm{X} \leq 136,5$ & 46 & $39,3 \%$ \\
\cline { 2 - 5 } & Sedang & $94,5<\mathrm{X} \leq 115,5$ & 0 & $0 \%$ \\
\cline { 2 - 5 } & Rendah & $73,5<\mathrm{X} \leq 94.5$ & 0 & $0 \%$ \\
\cline { 2 - 5 } & Sangat Rendah & $\mathrm{X} \leq 73,5$ & 0 & $0 \%$ \\
\hline Dukungan sosial keluarga & Sangat Tinggi & $123 \leq \mathrm{X}$ & 65 & $55,6 \%$ \\
\cline { 2 - 5 } & Tinggi & $104,5<\mathrm{X} \leq 123,5$ & 52 & $44,4 \%$ \\
\cline { 2 - 5 } & Sedang & $85,5<\mathrm{X} \leq 104,5$ & 0 & $0 \%$ \\
\cline { 2 - 5 } & Rendah & $66,5<\mathrm{X} \leq 85,5$ & 0 & $0 \%$ \\
\cline { 2 - 5 } & Sangat Rendah & $\mathrm{X} \leq 66,5$ & 0 & $0 \%$ \\
\hline
\end{tabular}

Sebelum dilakukan uji hipotesis, terlebih dahulu dilakukan uji asumsi yang meliputi uji normalitas dan uji linearitas. Hasil uji normalitas pada penelitian ini, sebaran data variabel minat berwirausaha memiliki nilai Kolmogorov-Smirnov $Z$ sebesar 1.177 dengan taraf signifikan 0.125 ( $\mathrm{p}>0.05)$, maka dapat dikatakan bahwa data minat berwirausaha terdistribusi secara normal. Sedangkan variabel dukungan sosial keluarga memiliki nilai KolmogorovSmirnov $Z$ sebesar 0.914 dengan taraf signifikan 0.374 ( $>>0.05)$, maka dapat dikatakan bahwa data dukungan sosial keluarga terdistribusi secara normal. Hasil uji dari linearitas menunjukan bahwa minat berwirausaha dengan dukungan sosial keluarga memiliki $F=50,106$ dan $p=0,000$ $(p<0.05)$. Karena signifikansi kurang dari 0,05 maka, dapat disimpulkan bahwa antara variabel minat berwirausaha dengan dukungan sosial keluarga memiliki hubungan yang linear.

Hasil uji normalitas dan uji linearitas menunjukan bahwa data terkumpul memenuhi syarat untuk dilakukan analisis selanjutnya. Hasil analisis data menunjukan koefisien korelasi (r) sebesar 0,477 dengan $\mathrm{p}=0,000(\mathrm{p}<0.01)$ antara variabel minat berwirausaha dan dukungan sosial keluarga, hal ini menunjukan adanya korelasi positif antara dua variabel.

Penelitian ini memiliki tujuan agar dapat mengetahui hubungan antara dukungan sosial keluarga dengan minat berwirausaha. Subjek dalam penelitian ini adalah siswa-siswi kelas XI SMK Negeri 4 Surakarta yang sudah mendapatkan mata pelajaran kewirausahaan. Penelitian 
ini melibatkan 117 siswa dan siswi dengan jumlah 71 siswi ( 60,68\% ) dan 46 siswa (39,31\%). Hasil analis data dengan memakai analisis product moment menunjukan bahwa terdapat hubungan antara dukungan sosial keluarga dengan minat berwirausaha, dengan koefisien korelasi rxy $=0,477$ dengan $\mathrm{p}=0,000(\mathrm{p}<0.01)$. Artinya bahwa terdapat suatu hubungan yang sangat signifikan antara dukungan sosial keluarga dengan minat berwirausaha. Hasil di atas dapat menunjukan bahwa hipotesis yang peneliti ajukan diterima, bahwa ada hubungan yang positif antara dukungan sosial keluarga dengan minat berwirausaha pada siswa SMK Negeri 4 Surakarta. Semakin tinggi dukungan sosial keluarga maka semakin tinggi minat berwirausaha siswa, dan begitu juga sebaliknya.

Salah satu faktor yang mempengaruhi seseorang untuk berminat dalam dunia wirausaha dapat dilihat dari dukungan sosial keluarga, yaitu dukungan dari orang terdekat mereka. Dukungan sosial keluarga merupakan bentuk kasih sayang yang diberikan oleh keluarga untuk anggota keluarga lainnya, dengan adanya keluarga akan ada dorongan, bantuan, dan penerimaan apabila sedang dalam kesulitan. Tersedinya dukungan sosial keluarga akan memberikan perasaan senang bahwa dirinya diperhatikan, dihargai, dipenuhi kebutuhannya, dibimbing dan keluarga akan memberikan pengalaman kepada individu. Menurut Wibowo (2011) seseorang akan timbul minatnya dalam berwirausaha jika memiliki dukungan sosial dari lingkungan keluarga terutama dari orang tua, sehingga peran dari orang tua memiliki peran penting dalam menumbuhkan minat anak. Hal ini didukung pendapat Alma (2016) bahwa orang yang diidolakan yang merupakan seorang pengusaha, baik itu dari orang tua, saudara, teman ataupun pengusaha dapat menumbuhkan minat berwirausaha yaitu dengan role models. Temuan dalam penelitian ini didukung dengan hasil wawancara dengan guru mata pelajaran kewirausahaan SMK Negeri 4 Surakarta pada tanggal 27 Mei 2018 pukul 13.25 mengatakan jika keluarga sangat mendorong anaknya agar belajar berwirausaha, ini terbukti ketika siswa diberikan tugas berwirausaha, keluarga ikut serta mencarikan keperluan yang diperlukan siswa, keluarga ikut memberikan dukungan dengan membantu setiap kesulitan siswa saat ada tugas berwirausaha. Lingkungan keluarga mempengaruhi tumbuhnya kepribadian wirausaha anaknya.

Senada dengan penelitian yang dilakukan oleh Suhartini (2011) peletak utama bagi perkembangan dan pertumbuhan seorang anak adalah keluarga, karena awal terbentuknya kepribadian ditentukan oleh keluarga. Terutama Orangtua yang merupakan pihak yang bertanggung jawab penuh dalam proses perkembangan anak, saat anak masih kecil orang tua dapat menumbuhkan rasa tanggung jawab dan mengembangkan kreatifitas serta pengaruh dari 
orang-orang terdekat memiliki kekuatan yang besar dalam mengembangkan potensi-potensi yang dimilikinya.

Tinggi rendahnya dukungan sosial keluarga dengan minat berwirausaha pada siswa SMK Negeri 4 Surakarta dapat diketahui dengan cara membandingkan hasil rata-rata empirik subjek dengan rata-rata hipotetik. Mean empirik pada variabel dukungan sosial keluarga sebesar 126,5 lebih tinggi dari mean hipotetiknya, yaitu 95, sehingga dapat disimpulkan bahwa siswa memiliki dukungan sosial keluarga yang sangat tinggi dengan presentase 55,6 \%. Mean empirik pada variabel minat berwirausaha sebesar 139,6 lebih tinggi pada mean hipotetiknya, yaitu 105. Sehingga dapat ditarik kesimpulan bahwa siswa memiliki minat berwirausaha yang sangat tinggi dengan presentase $60,7 \%$.

Hal ini sesuai data yang peneliti peroleh dari pihak SMK Negeri 4 Surakarta, bahwa sekolah memiliki jadwal pelibatan orang tua disekolah yang diadakan pada bulan Juli, Agustus, September, Desember, Januari, Maret, dan Juni. Sehingga dengan adanya pertemuan rutin wali murid dengan pihak sekolah akan lebih mudah untuk mengubah pola pikir orang tua yang memiliki orientasi bahwa anak mereka harus menjadi PNS (pegawai negeri sipil). Orang tua dan masyarakat perlu dipahamkan bahwa bekerja tidaklah harus disektor formal, namun melakukan kegiatan yang jujur, halal, tidak melanggar norma dan mampu mendapatkan penghasilan, tekun sesuai dengan keahliannya dan kemampuannya. Keuntungan dalam menumbuhkan mindset kewirausahaan, selain menumbuhkan keinginan untuk berwirausaha juga akan mampu menjadikan pola hidup masyarakat dalam mengoptimalkan sumber daya yang dimilikinya, inovatif, lebih kreatif, tidak mudah mengeluh dalam menghadapi permasalahan wirausaha dan disiplin.

Tidak hanya pertemuan rutin terhadap keluarga yang dilakukan pihak sekolah untuk menumbuhkan minat berwirausaha, namun pada dasarnya pendidikan SMK sudah mempunyai ciri khusus dalam menghasilkan lulusan yang siap kerja, siswa tidak hanya dipersiapkan untuk mencari pekerjaan namun juga dipersiapkan dalam menciptakan peluang kerja sendiri dengan berwirausaha.

Selanjutnya, dari hasil analisis yang dilakukan ditemukan bahwa sumbangan efektif variabel dukungan sosial keluarga terhadap minat berwirausaha adalah $22,7 \%$ sisanya $77,3 \%$ di pengaruhi oleh faktor lain. Faktor lain yang dimaksud adalah faktor-faktor yang mempengaruhi minat berwirausaha yang dikemukakan oleh Hisrics (dalam Franky,dkk, 2014) yaitu pendidikan, nilai personal, dan pengalaman kerja. Selain dari keluarga peletak dasar bagi perkembangan dan pertumbuhan anak juga dipengaruhi oleh lingkungan sekolah, yaitu 
pendidikan. Dalam hal ini, pendidikan yang dimaksud adalah lingkungan sekolah tempat penelitian, seperti yang sudah dijelaskan di atas bahwa pendidikan SMK tidak hanya menyiapkan lulusan yang siap kerja pada dunia industri akan tetapi juga menyiapkan dan mengubah mindset siswanya untuk mengenal dunia wirausaha. Didukung oleh pernyataan Alma (2016) pendidikan formal dapat membantu memberikan pemahaman tentang proses kewirausahaan, tantangan kedepan dalam berwirausaha dan keterampilan dalam memanagemen agar berhasil. Pendidikan sangat penting untuk modal dalam dunia wirausaha terutama dalam menjaga usahanya dan mengatasi segala masalah dalam usahanya.

Sedangkan nilai personal yang dimaksud disini bagaimana individu dapat melihat sebuah peluang usaha dengan mampu menyesuaikan diri dan melihat perubahan pasar dengan menghasilkan produk baru dengan memberikan pelayanan berkualitas seperti memiliki sopan santun, etika yang baik terhadap konsumen dan mampu memanagemen usahanya. Senada dengan penelitian yang dilakukan oleh Mbayak dan Eko (2015) seseorang yang memiliki nilai personal dalam berwirausaha akan lebih percaya dengan kemampuan dirinya, sehingga dirinya terdorong untuk dapat menciptakan suatu produk, memikirkan strategi pelayan, dan memikirkan perubahan pasar. Selanjutnya pengalaman kerja. ketidakpuasan dalam suatu pekerjaan yang dihadapi, pekerjaan yang kurang menantang, kebosanan pada pekerjaan yang selalu monoton sering kali akan menumbuhkan minat berwirausaha. Karena pengalaman kerja sangat diperlukan untuk dapat mengoperasikan suatu usaha agar dapat mengatasi suatu permasalahan dalam usahanya dengan tenang dan tidak tergesa-gesa agar usaha tetap stabil. Hal ini diperkuat dengan penelitian yang dilakukan oleh Scoott dan Twomey (dalam Indarti dan Rostiana, 2008) menyebutkan bahwa seseorang yang sudah mempunyai pengalaman dalam bidang usaha, dipastikan individu tersebut mempunyai gambaran dalam berwirausaha. Sehingga memiliki pondasi ketahanan dalam membangun suatu usaha.

Dalam penelitian ini memiliki keterbatasan, yaitu pembahasan pada variabel minat berwirausaha yaitu tidak membahas minat berwirausaha laki-laki dan perempuan yang lebih dominan, sehingga hanya sedikit informasi yang dapat diambil. Diharapkan untuk peneliti selanjutnya dapat memperluas dengan membedakan minat berwirausaha laki-laki dan perempuan. 


\section{SIMPULAN}

Berdasarkan hasil analisis data yang dilakukan, maka dapat disimpulkan bahwa ada hubungan positif yang signifikan antara minat berwirausaha dengan dukungan sosial keluarga pada siswa SMK Negeri 4 Surakarta, semakin tinggi dukungan sosial keluarga maka semakin tinggi pula minat berwirausaha pada siswa SMK Negeri 4 Surakarta dan sebaliknya semakin rendah dukungan sosial keluarga maka semakin rendah pula minat berwirausaha pada siswa SMK Negeri 4 Surakarta.

Berdasarkan hasil kesimpulan diatas, maka peneliti memberikan beberapa saran terhadap berbagai pihak yang berkepentingan dalam penelitian ini, yaitu: 1) Bagi siswa SMK, siswa sebaiknya mengikuti berbagai kegiatan yang diberikan oleh sekolah mengenai wawasan tentang kewirausahaan. 2) Bagi orang tua siswa, diharapkan dapat membantu menyiapkan keperluan siswa untuk menunjang minat berwirausaha dengan memberikan bantuan berupa jasa, informasi, perhatian dan materi agar anak memiliki semangat untuk berwirausaha. 3) Bagi sekolah tempat penelitian, pihak sekolah diharapkan terus memberikan dorongan kepada siswa untuk mengembangkan minat berwirausaha siswa. 4) Bagi peneliti selanjutnya, hendaklah menambah variabel lain seperti pendidikan, nilai personal dan pengalaman kerja sebagai variabel yang ikut dalam mempengaruhi minat berwirausaha.

\section{DAFTAR PUSTAKA}

Alma, Buchari. (2016). Kewirausahaan. Alfabeta.

Aprilianty, E. 2012. Pengaruh Kepribadian Wirausaha, Pengetahuan Kewirausahaan, dan Lingkungan Terhadap Minat Berwirausaha Siswa SMK. Jurnal Pendidikan Vokasi. 3 (2), 311 .

Berita resmi Badan Pusat Statistika. hhtp//www.bps.go.id. Diakses jam 13.30 tanggal 8 Oktober 2017.

Franky., dkk. (2014). Dasar-dasar Kewirausahaan. Teori dan Praktek. Indeks.

Hendro. (2011). Dasar-Dasar Kewirausahaan. Erlangga.

House, James S. (1987). Social Support and Social Structure. Jurnal Sociological Forum. 2

Ihsan, F. (2011). Dasar-dasar Kependidikan. Rineka Cipta

Indarti, Nurul. dan Rostiani, Rokhima. (2008). Intensi Kewirausahaan Mahasiswa Studi

Perbandingan antara Indonesia, Jepang, dan Norwegia. Jurnal Ekonomika dan Bisnis Indonesia. Fakultas Ekonomi Universitas Gajah Mada Yogyakarta. 23 (4), 1-27. 
Mbayak Ginting \& Eko Yuliawan. (2015). Analisis Faktor-Faktor yang Mempengaruhi Minat Berwirausaha Mahasiswa (studi kasus pada STMIK mikroskil medan). Jurnal wira ekonomi mikroskil. 5(1), April 2015.

Saiman, Leonardus. (2009). Kewirausahaan Teori, Praktik, dan Kasus-kasus. Salemba Empat.

Suhartini, L \& Sirine, H. (2011). Faktor-faktor yang berpengaruh terhadap niat kewirausahaan (studi terhadap mahasiswa universitas Kristen satya wacana salatiga). Jurnal managemen dan kewirausahaan.

Wibowo, Muladi. (2011). Pembelajaran Kewirausahaan dan Minat Wirausaha Lulusan SMK. Jurnal Ekplanasi. 6 (2). 